\title{
Domain-swapping of mesophilic xylanase with hyper-thermophilic glucanase
}

\author{
Liangwei Liư ${ }^{*}$, Linmin Wang ${ }^{1}$, Zhang Zhang ${ }^{1}$, Xiaodan Guo ${ }^{1}$, Xiangqian Li $^{2}$ and Hongge Chen ${ }^{1,3}$
}

\begin{abstract}
Background: Domain fusion is limited at enzyme one terminus. The issue was explored by swapping a mesophilic Aspergillus niger GH11 xylanase (Xyn) with a hyper-thermophilic Thermotoga maritima glucanase (Glu) to construct two chimeras, Xyn-Glu and Glu-Xyn, with an intention to create thermostable xylanase containing glucanase activity.

Results: When expressed in E. coli BL21(DE3), the two chimeras exhibited bi-functional activities of xylanase and glucanase. The Xyn-Glu Xyn moiety had optimal reaction temperature $\left(T_{\text {opt }}\right)$ at $50{ }^{\circ} \mathrm{C}$ and thermal in-activation half-life $\left(\mathrm{t}_{1 / 2}\right)$ at $50^{\circ} \mathrm{C}$ for $47.6 \mathrm{~min}$, compared to $47^{\circ} \mathrm{C}$ and $17.6 \mathrm{~min}$ for the Xyn. The Glu-Xyn Xyn moiety had equivalent $T_{\text {opt }}$ to and shorter $\mathrm{t}_{1 / 2}(5.2 \mathrm{~min})$ than the $\mathrm{Xyn}$. Both chimera Glu moieties were more thermostable than the Glu, and the three enzyme $T_{\text {opt }}$ values were higher than $96^{\circ} \mathrm{C}$. The Glu-Xyn Glu moiety optimal pH was 5.8, compared to 3.8 for the Xyn-Glu Glu moiety and the Glu. Both chimera two moieties cooperated with each other in degrading substrates.

Conclusions: Domain-swapping created different effects on each moiety properties. Fusing the Glu domain at C-terminus increased the xylanase thermostability, but fusing the Glu domain at N-terminus decreased the xylanase thermostability. Fusing the Xyn domain at either terminus increased the glucanase thermostability, and fusing the Xyn domain at C-terminus shifted the glucanase pH property 2 units higher towards alkaline environments. Fusing a domain at C-terminus contributes more to enzyme catalytic activity; whereas, fusing a bigger domain at $\mathrm{N}$-terminus disturbs enzyme substrate binding affinity.
\end{abstract}

Keywords: Xylanase, Glucanase, Domain-swapping, Fusing

\section{Background}

Enzyme is important in biomass conversion and renewable energy production. However, biotechnological condition demands for thermostable enzymes. Thermostability can be enhanced by fusing proper protein fragments, such as, the non-homologous fragments [1], the thermophilic xylanase homologous N-terminus [2,3], the hyper-thermophilic carbohydrate binding-module [4], and the Pseudoalteromonas arctica esterase OsmC domain [5]. Two catalytic domains, such as, xylanase and glucanase, can also be combined to create bi-functional chimeras [6-8]. However, the domain fusions were limited at xylanase one terminus. When fused at the other terminus, the Clostridium thermocellum xylanase and

\footnotetext{
* Correspondence: LLW321@yahoo.com.cn

${ }^{1}$ Life Science College, Henan Agricultural University, 95 Wenhua Road, Zhengzhou, Henan 450002, China

Full list of author information is available at the end of the article
}

Thermotoga maritima glucanase activities were damaged [7-9]. Thereby, domains need to be swapped with each other in fusion investigation.

Xylanase (EC3.2.1.8) is widely used in feed, flour, baking industry, pulp bleaching, etc [3,10,11]. An Aspergillus niger xylanase (Xyn) has high catalytic activity (GenBank: EU375728) [12]. The 185 residue enzyme is more suitable for domain fusion investigation, because it is the smallest xylanase in GH11 family. However, the Xyn optimal temperature for activity $\left(\mathrm{T}_{\mathrm{opt}}\right)$ is $47{ }^{\circ} \mathrm{C}$, and its thermal inactivation half-life $\left(\mathrm{t}_{1 / 2}\right)$ at $50{ }^{\circ} \mathrm{C}$ is $17.6 \mathrm{~min}$ [4]. To break down complicated biomass [13], the mesophilic fungal Xyn needs enhanced thermostability and synergistic glucanase activity. An ideal partner is the $T$. maritima glucanase (Glu) (EC3.2.1.4), because it is hyper-thermophilic and 258 residue big $\left(\mathrm{Met}_{1}-\mathrm{Glu}_{258}\right)$ $[14,15]$. Linker-peptide is also important for enzyme thermostability [16,17], because each domain needs 
necessary space to form to active conformation [4]. A linker-peptide $\left(\mathrm{Pro}_{692}-\mathrm{Gly}_{713}\right)$, which was selected from the hyper-thermophilic T. maritima xylanase A [10], was confirmed having enough space for connecting two domains [4]. Thereby, the 22 residue linker-peptide is used to connect the $A$. niger Xyn with the T. maritima Glu to construct two chimeras, Xyn-Glu and Glu-Xyn (Figure 1). After expression in E. coli BL21(DE3), the two chimeras exhibit bi-functional activities of xylanase and glucanase. Especially, fusing the Glu domain at Cterminus increases the mesophilic xylanase $T_{\text {opt }}$ value and thermostability. The domain-swapping provides more insights into enzyme fusion investigation.

\section{Results and discussion}

\section{Construction of chimeras}

After step-extension PCR, the xyn-glu and glu-xyn construct genes appeared on the $1.4 \%$ electrophoresis gel as discrete DNA bands at $\sim 1.4 \mathrm{~kb}$, approximately the combined molecular masses of contributing gene fragments (Figure 1). After the sequence accuracies had been confirmed for the recombinant plasmids (GenBank: JQ793634, JQ793635), transformed cells containing
pET20b-xyn-glu and pET20b-glu-xyn were induced to express the chimeric xylanases. The two proteins, XynGlu and Glu-Xyn, appeared on the $10 \%$ SDS-PAGE gel as discrete bands at $\sim 53 \mathrm{kDa}$. As expected, the molecular masses are approximately the sum of two contributing moieties (Figure 1, Table 1), because the chimeras have residues equaling to the sum of Xyn, Glu, and linker peptide.

\section{Properties of the chimeras}

When properties were assayed, the two chimeras exhibited bi-functional activities of xylanase and glucanase. When xylanase activity was determined, both chimera Xyn moieties had optimal reaction $\mathrm{pH}\left(\mathrm{pH}_{\text {opt }}\right)$ at 3.8, equivalent to the Xyn. Thus, fusing the Glu domain at either terminus did not alter the xylanase $\mathrm{pH}$ property. Both chimera Xyn moiety activities decrease at $\mathrm{pH}$ higher than 3.8 (Figure 2). As to thermal property, the Xyn-Glu Xyn moiety had optimal reaction temperature, $\mathrm{T}_{\text {opt }}$, at $50{ }^{\circ} \mathrm{C}$, compared to $47{ }^{\circ} \mathrm{C}$ for the $\mathrm{Xyn}$ (Figure 3A). The Xyn moiety had $\mathrm{t}_{1 / 2}$ at $50{ }^{\circ} \mathrm{C}$ for 47.6 min, 2.7-times longer than the Xyn (Figure 3B, Table 1). Fusing the Glu domain at $\mathrm{C}$-terminus increased

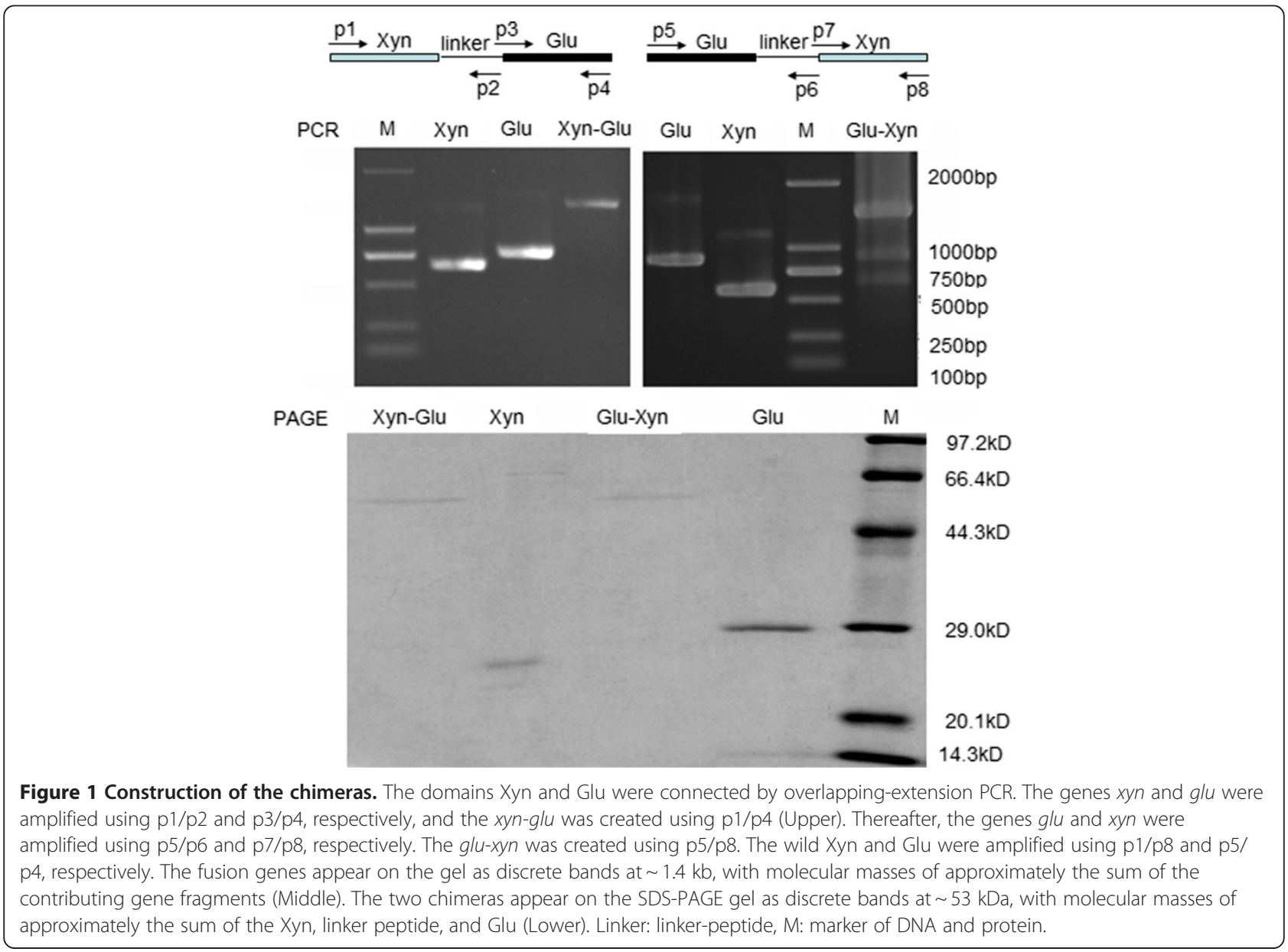


Table 1 Enzyme property of the chimeras

\begin{tabular}{|c|c|c|c|c|c|c|c|c|}
\hline \multirow[t]{2}{*}{ Enzyme } & \multicolumn{3}{|l|}{ Xyn Activity } & \multicolumn{3}{|c|}{ Glu Activity } & \multicolumn{2}{|l|}{ Physical feature } \\
\hline & $t_{1 / 2}-50^{\circ} \mathrm{C}(\mathrm{min})$ & $\mathrm{pH}_{\text {opt }} / \mathrm{T}_{\text {opt }}\left({ }^{\circ} \mathrm{C}\right)$ & $\begin{array}{l}\mathrm{K}_{\mathrm{m}}(\mathrm{mg} / \mathrm{ml}) / \\
\mathrm{K}_{\text {cat }}\left(\mathrm{s}^{-1}\right)\end{array}$ & $\begin{array}{l}\mathrm{t}_{1 / 2}-95^{\circ} \mathrm{C} \\
(\mathrm{min})\end{array}$ & $\begin{array}{l}\mathrm{pH}_{\text {opt }} / \\
\mathrm{T}_{\text {opt }}\left({ }^{\circ} \mathrm{C}\right) \\
\end{array}$ & $\begin{array}{l}\mathrm{K}_{\mathrm{m}}(\mathrm{mg} / \mathrm{ml}) / \\
\mathrm{K}_{\text {cat }}\left(\mathrm{s}^{-1}\right)\end{array}$ & $\begin{array}{l}\text { MM(kDa) Apparent/ } \\
\text { Theoretical }\end{array}$ & $\begin{array}{l}\text { Number of } \\
\text { residues/pl }\end{array}$ \\
\hline Xyn-Glu & 47.6 & $3.8 / 50$ & $10.2 / 118.9$ & $>99.8$ & $3.8 / \geq 96$ & $5.9 / 3.4$ & $53 / 53.2$ & $465 / 4.5$ \\
\hline Glu-Xyn & 5.2 & $3.8 / 47$ & $44.2 / 50.2$ & 99.8 & $5.8 / \geq 96$ & $1.88 / 15.9$ & $53 / 53.2$ & $467 / 4.5$ \\
\hline Xyn & 17.6 & $3.8 / 47$ & $12.3 / 49.2$ & & & & $25 / 21.1$ & $185 / 4.5$ \\
\hline Glu & & & & 96.2 & $3.8 / \geq 96$ & $1.87 / 2.6$ & $29 / 30.9$ & $258 / 4.78$ \\
\hline
\end{tabular}

$\mathrm{pH}_{\mathrm{opt}}$ : optimal reaction $\mathrm{pH}, \mathrm{T}_{\mathrm{opt}}$ : optimal reaction temperature, $\mathrm{t}_{1 / 2}(\mathrm{~min})$ : thermal inactivation half-life, the residual xylanase activity was assayed after incubation at $50{ }^{\circ} \mathrm{C}$ at 10 -min intervals from $0-30 \mathrm{~min}$, and the residual glucanase activity was assayed after incubation at $95{ }^{\circ} \mathrm{C}$ at 20 -min intervals from $0-60$ min. $\mathrm{K}_{\mathrm{m}}$ and $\mathrm{K}_{\text {cat }}$ were determined for birch-wood xylan and carboxymethyl cellulose sodium (CMC).

the xylanase thermo-activity and thermostability. In contrast, the Glu-Xyn Xyn moiety had $\mathrm{T}_{\text {opt }}$ at $47^{\circ} \mathrm{C}$, equivalent to the Xyn (Figure 3A). However, the Xyn moiety had $t_{1 / 2}$ value at $50{ }^{\circ} \mathrm{C}$ for $5.2 \mathrm{~min}$, shorter than the wild Xyn. Fusing the Glu domain at N-terminus did not alter the xylanase thermal activity, but decreased its thermostability (Figure 3B, Table 1).

When glucanase activity was determined, both chimera Glu moiety $\mathrm{T}_{\text {opt }}$ were higher than $96{ }^{\circ} \mathrm{C}$, similar to the Glu (Figure 4A). The Glu-Xyn Glu moiety had $\mathrm{t}_{1 / 2}$ at $95{ }^{\circ} \mathrm{C}$ for $99.8 \mathrm{~min}$, and the Xyn-Glu Glu moiety had $t_{1 / 2}$ clearly longer than 99.8 min (Figure 4B, Table 1 ). The Glu activity increased after incubation at $95{ }^{\circ} \mathrm{C}$, because the chimera $\mathrm{T}_{\text {opt }}$ was higher than $96{ }^{\circ} \mathrm{C}$ and its thermostability was significantly high. Fusing the Xyn domain at either terminus, especially, at N-terminus, increased the glucanase thermostability. The Glu-Xyn Glu moiety $\mathrm{pH}_{\text {opt }}$ was 5.8, 2 units higher than the XynGlu Glu moiety and the wild Glu (Figure 2). Fusing the Xyn domain at C-terminus significantly shifted the glucanase $\mathrm{pH}$ property to higher $\mathrm{pH}$ environments.
When the kinetics were determined, the xylanase catalytic efficiencies $\left(\mathrm{K}_{\mathrm{cat}}\right)$ toward birch-wood xylan increased in the order Xyn $<$ Glu-Xyn $<$ Xyn-Glu. The substratebinding affinities $\left(K_{m}\right)$ for birch-wood xylan increased in the order Glu-Xyn $<$ Xyn $<$ Xyn-Glu (Table 1). Fusing the Glu domain at either terminus cooperated with the xylanase to degrade substrate; however, fusing the Glu domain at $\mathrm{N}$-terminus interfered with the xylanase substratebinding affinity. In contrast, the glucanase catalytic efficiencies $\left(\mathrm{K}_{\text {cat }}\right)$ toward carboxymethyl cellulose sodium $(\mathrm{CMC})$ increased in the order Glu $<$ Xyn-Glu $<$ Glu-Xyn. The substrate-binding affinities $\left(\mathrm{K}_{\mathrm{m}}\right)$ for CMC increased in the order Xyn-Glu $<$ Glu = Glu-Xyn (Table 1). Fusing the Xyn domain at either terminus cooperated with the glucanase to degrade substrate; however, fusing the Xyn domain at $\mathrm{N}$-terminus interfered with the glucanase substrate-binding affinity. Thus, a domain, especially, a bigger one, is better fused at C-terminus for enzyme getting higher activity.

The Xyn-Glu Xyn moiety $\mathrm{T}_{\text {opt }}$ was $3{ }^{\circ} \mathrm{C}$ higher than the $\mathrm{Xyn}$. This is consistent with the $\mathrm{Xyn} \mathrm{T}_{\text {opt }} 3{ }^{\circ} \mathrm{C}$ increase

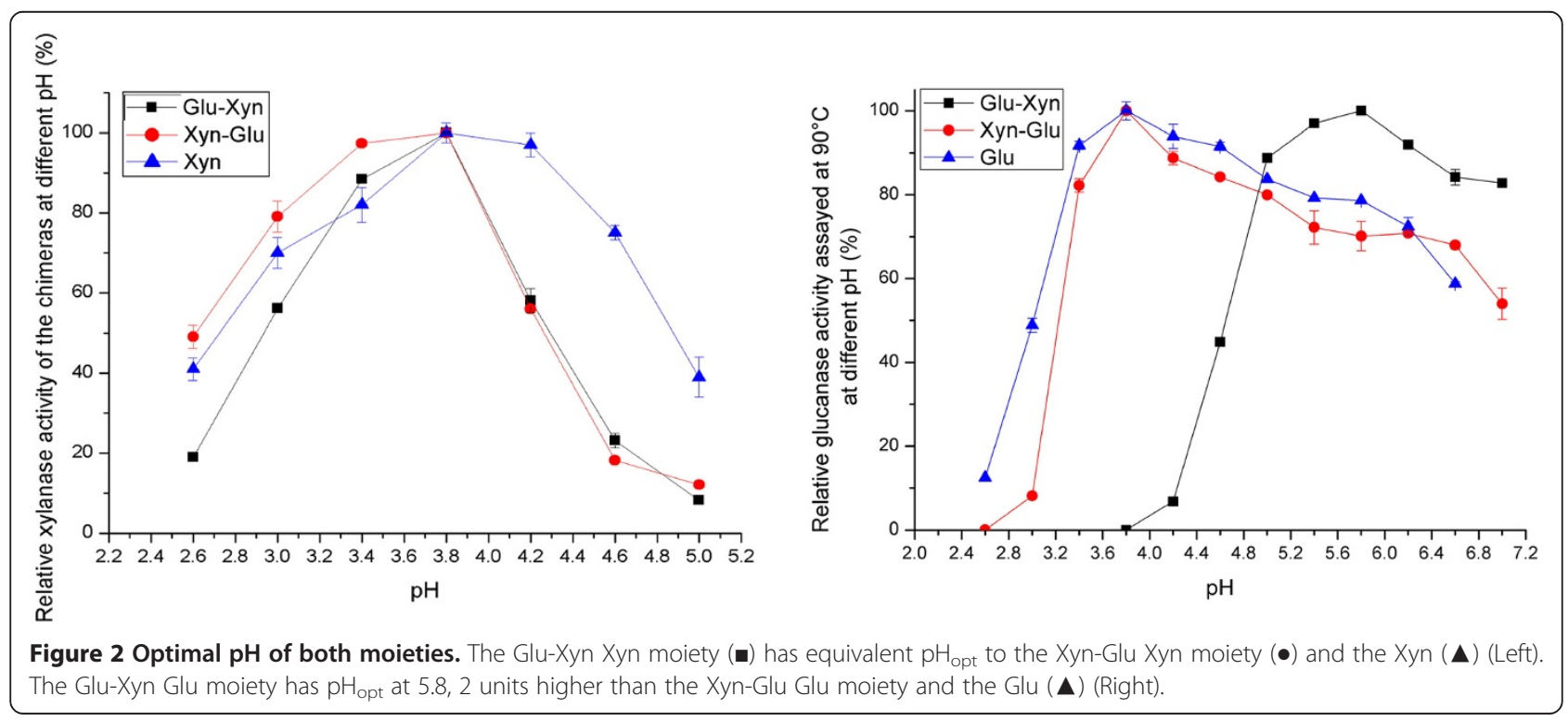




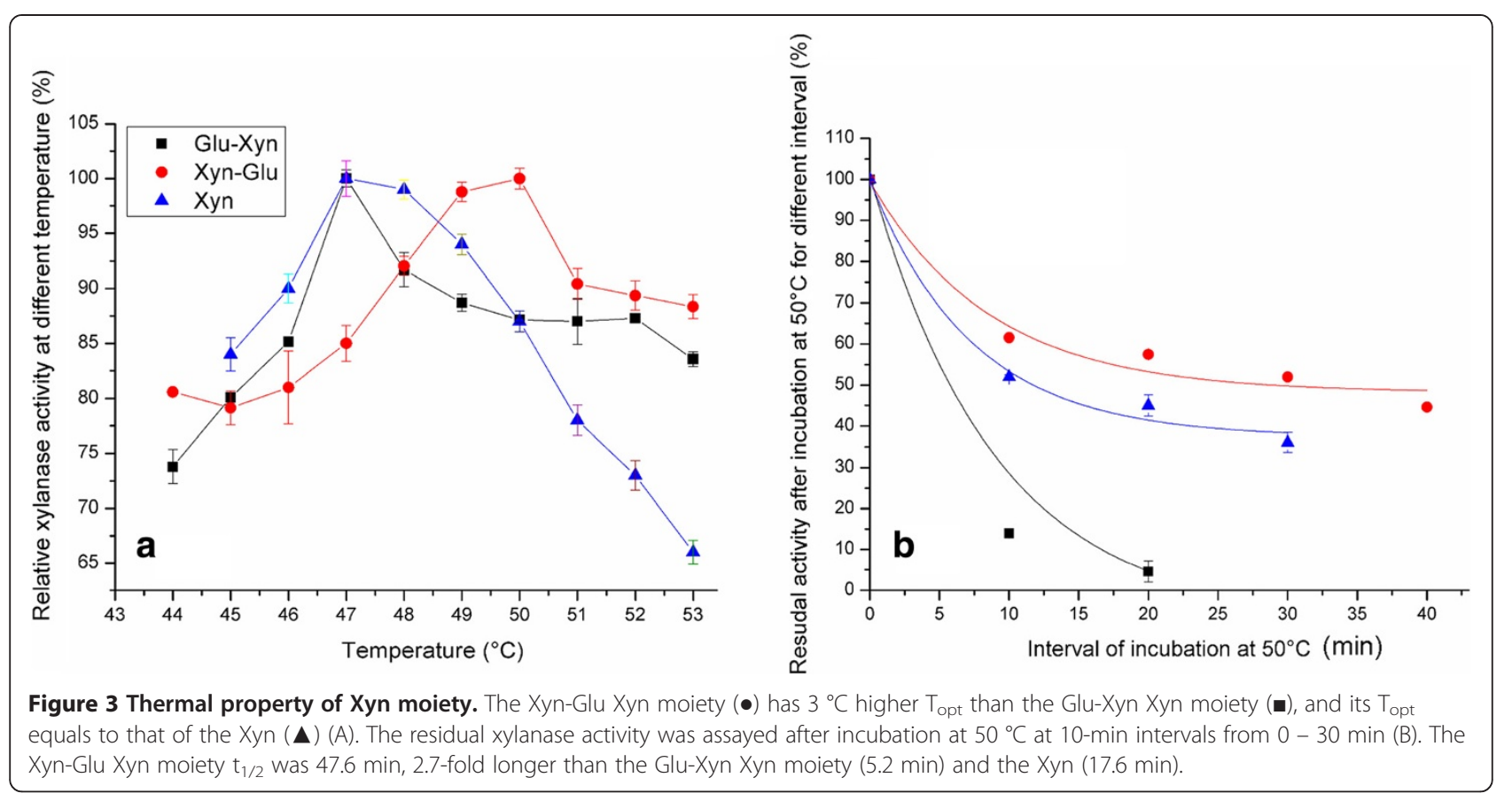

after fusing the hyper-thermophilic carbohydrate-binding module [4]. Previous domains were mainly fused at enzyme one terminus. For example, the Bacillus subtilis xylanase was fused at the Bacillus amyloliquefaciens glucanase C-terminus [6]. The T. maritima xylanase was fused at the T. maritima glucanase $\mathrm{C}$-terminus [8]. The $T$. maritima $\beta$-glucosidase was fused at the T. maritima cellulase C-terminus [9]. When the domains were fused at the other terminus, the chimeras lost both moiety activities $[6,8]$. There are so many xylanase domains fused at glucanase $\mathrm{C}$-terminus. The situation probably indicates that xylanase locates naturally at downstream of glucanase. It is probably a trace of natural evolution, because the site location order is shown in the glucanase-xylanase bi-functional protein selected from meta-genome library [13]. The domain-swapping created different effects on each moiety properties. The N-terminal Glu domain decreased the xylanase thermostability; however, the Cterminal Glu domain increased the xylanase thermostability. The Glu has 258 residues, 1.4-times bigger than the 185 residue Xyn. Probably, the C-terminal Glu protects the Xyn from thermal inactivation; whereas, the $\mathrm{N}$ -
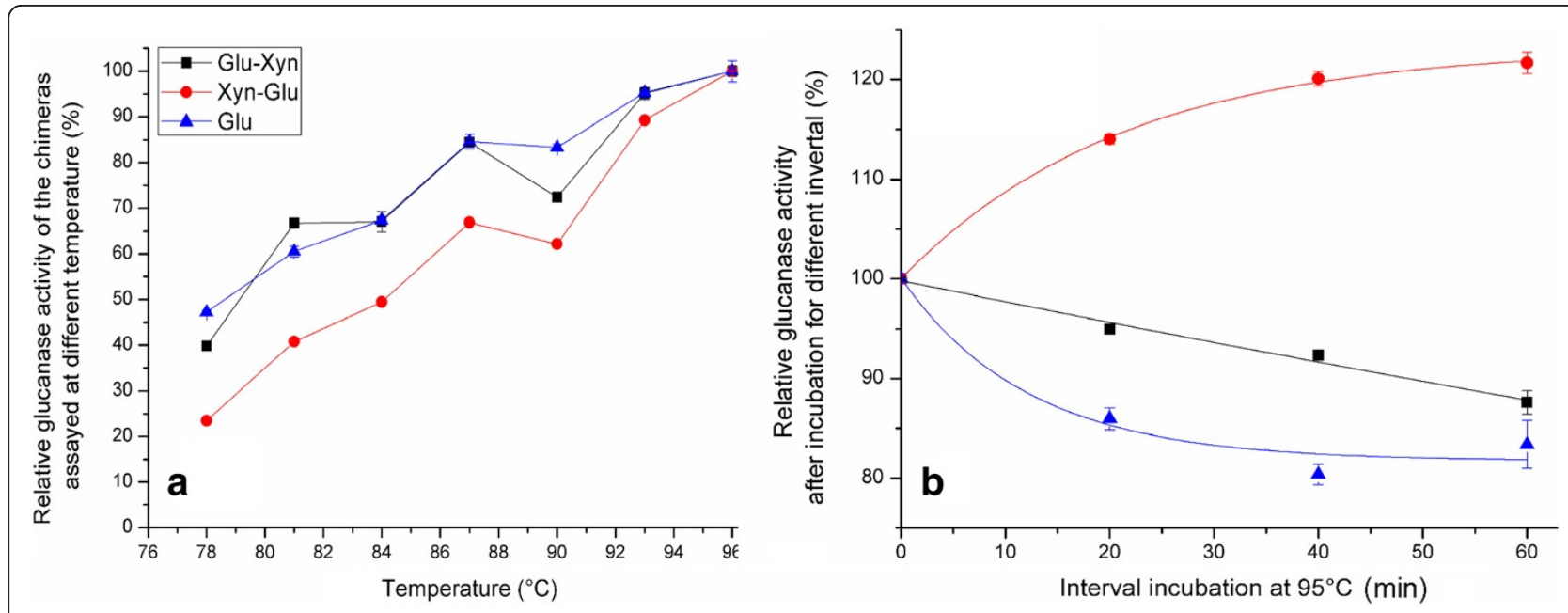

Figure 4 Thermal property of Glu moiety. Both chimera Glu moiety $T_{\text {opt }}$ values were higher than $96{ }^{\circ} \mathrm{C}$, similar to the wild Glu ( $(\mathbf{\Delta})(\mathrm{A})$. The residual glucanase activity was assayed after incubation at $95^{\circ} \mathrm{C}$ at 20 -min intervals from $0-60$ min (B). The Glu-Xyn Glu moiety ((-) $t_{1 / 2}$ was $99.8 \mathrm{~min}$, shorter than the Xyn-Glu Glu moiety $(\bullet)$ and longer than the Glu (96.2 min). 
terminal Glu interferes with the Xyn folding and confirmation-forming, therefore, interferes with its thermostability. In contrast, fusing the Xyn at either terminus, especially, at N-terminus, increased the glucanase thermostability. In addition, fusing the Xyn at C-terminus shifted the glucanase $\mathrm{pH}_{\mathrm{opt}} 2$ units higher to alkaline environment. The result probably reflects that glucanase cooperates with other catalytic domains on both sides, because two glucanases, CelA and CelB, are shown connecting together in the $T$. maritima genome (EMBL-Bank: Z69341.1) [14].

Each domain has a natural conformation to perform catalytic activity. Therefore, each domain needs a necessary space to form to an active conformation [4,17-19], that is the reason why a suitable linker-peptide is so important. The decreased chimera $\mathrm{T}_{\mathrm{opt}}$ values in previous investigations are attributed to linker-peptide interference. For example, fusing the $B$. amyloliquefaciens $\beta$ glucanase decreased the $B$. subtilis xylanase $\mathrm{T}_{\text {opt }}$ value and thermostability [6]. Fusing the T. maritima glucanase also decreased the xylanase $\mathrm{T}_{\text {opt }}$ value. When the domains were fused at other terminus, many enzyme activities were damaged $[6,8]$. The phenomenon is attributed to lack of linker-peptide. For example, the glucanases lost activities when fused at the other terminus $[8,9]$. To exclude the linker-peptide disturbance, we used the natural 22 residue linker-peptide to connect the Glu and Xyn. In addition, boundary determination is important for each domain to have complete residues. Only a domain has complete residues, can it form to an active confirmation. In the meantime, we have to eliminate the extra residues encoded by unnecessary endo-nuclease sites in expression vectors. Otherwise, the extra residues would disturb enzyme properties [20]. Thereby, NdeI and XhoI were used to delete the unnecessary endo-nuclease sites within the pET20b(+).

\section{Conclusions}

Through the natural 22 residue linker-peptide, the mesophilic $A$. niger Xyn was fused and swapped with the hyper-thermophilic T. maritima Glu. After expression in E. coli, both chimeras exhibited bi-functional activities of xylanase and glucanase. Especially, the Xyn-Glu Xyn moiety had $3{ }^{\circ} \mathrm{C}$ higher $\mathrm{T}_{\text {opt }}$ and 2.7-times higher thermostability than the Xyn. In addition to the synergistic glucanase activity, the fungal xylanase was enhanced thermostability. The domain-swapping created different effects on each moiety. Fusing the Glu domain at C-terminus increased the xylanase thermostability, but fusing the Glu domain at N-terminus decreased its thermostability. Fusing the Xyn domain at either terminus increased the glucanase thermostabilities, and fusing the Xyn domain at C-terminus shifted the glucanase
pH property 2 units higher towards alkaline environments. From the domain-swapping investigation, we can infer that a domain, especially a larger one, can only be fused at C-terminus to increase enzyme catalytic efficiency.

\section{Methods}

\section{Materials and reagents}

The A. niger Xyn gene (GenBank: EU375728), which encodes a 185 residue $\left(\mathrm{M}_{1}-\mathrm{S}_{185}\right)$ mature xylanase, was cloned into pET20b(+) (Novagen, Shanghai, China). The T. maritima Glu gene (GenBank: Z69341), which encodes a 258 residue $\left(\mathrm{M}_{1}-\mathrm{E}_{258}\right)$ mature glucanase, was cloned into pET20b(+) [15]. The 22 residue linkerpeptide $\left(\mathrm{P}_{692}-\mathrm{G}_{713}\right)$, which was selected from the T. maritima xylanase A (GenBank: Z46264), was used to connect the two domains [4] (Figure 1). Molecular reagents including Pfu polymerase, NdeI and XhoI, T4 DNA ligase, and DNA and protein marker were purchased from Takara Inc (Dalian, China).

\section{Construction of chimeras}

Through the linker-peptide, the two domains were fused together by overlapping-extension PCR. The standard PCR was carried out using $16.5 \mu \mathrm{g}$ of pET20b-xyn or pET20b-glu, $1.0 \mu \mathrm{l}$ of each of two related primers, $5 \mathrm{U}$ of Pfu polymerase, $4.0 \mu \mathrm{mol}$ of dNTPs, and $1 \times$ polymerase buffer with the following thermal cycling: 4 min denaturation at $95{ }^{\circ} \mathrm{C}$, followed by 30 cycles of 1 min denaturation at $94{ }^{\circ} \mathrm{C}, 1 \mathrm{~min}$ annealing at $33{ }^{\circ} \mathrm{C}$, and $1 \mathrm{~min}$ extension at $72{ }^{\circ} \mathrm{C}$. The reaction was completed with a 10 min extension at $72{ }^{\circ} \mathrm{C}$, unless described otherwise.

The genes $x y n$ and $g l u$ were amplified using $\mathrm{p} 1 / \mathrm{p} 2$ and $\mathrm{p} 3 / \mathrm{p} 4$ and annealing at $24{ }^{\circ} \mathrm{C}$ (Figure 1 ). The genes were recovered and served as templates (each $11 \mu \mathrm{g}$ ) to amplify the xyn-glu using $\mathrm{p} 1 / \mathrm{p} 4$, annealing at $62.4{ }^{\circ} \mathrm{C}$, and extending for $1.5 \mathrm{~min}$. The genes glu and $x y n$ were amplified using p5/p6 and p7/p8, and annealing at $36{ }^{\circ} \mathrm{C}$. The amplified genes were recovered and served as templates (each $11 \mu \mathrm{g}$ ) to amplify the glu-xyn using p5/p8, annealing at $65{ }^{\circ} \mathrm{C}$, and extending for $1.5 \mathrm{~min}$. The wild Xyn and Glu were amplified using p1/p8 and p5/p4,

\section{Table 2 Primers used to construct chimeras}

\begin{tabular}{ll}
\hline primer & sequence \\
\hline p1 & GGAATTCCATATGAGTGCCGGTATC \\
p2 & CCAACGCTCGTCAGGTACGAGTC \\
p3 & GACTCGTACCTGACGAGCGTTGG \\
p4 & CCAAATTACTCGAGAACTTCACAGAG \\
p5 & GAATTCCATATGACGAGCGTTGG \\
p6 & GTTGATACCGGCAGTCAGGTACGAGTCATCC \\
p7 & GGATGACTCGTACCTGAGTGCCGGTATCAAC \\
p8 & ATTACTCGAGAGAGGAGATCGTGAC \\
\hline
\end{tabular}


respectively. The primers were shown in Table 2, with italic shown for $N d e \mathrm{I} / \mathrm{XhoI}$ restriction sites and bold for homologous region.

Following PCR amplification, the genes were cloned into pET20b(+) plasmids that had been digested with $\mathrm{NdeI} / \mathrm{XhoI}$ to delete the redundant endo-nuclease sites. The recombinant plasmids were transformed E. coli BL21(DE3) competent cells, then extracted and sequenced with an ABI 3730 automated DNA sequencer to confirm gene accuracy (Invitrogen Biotechnology, Shanghai, China). Accurately transformed plasmids were grown and induced to produce enzymes according to standard protocols [4]. A C-terminal $\mathrm{His}_{6}$ tag was included in the chimera sequences to allow the proteins to be purified with $\mathrm{Co}^{2+}$-binding resin (Amersham Bioscience). Active fractions were pooled and further purified using sephadex G-25. The enzymes were detected using $12 \%$ polyacrylamide SDS-PAGE, stained with Coomassie brilliant G-250. Protein concentrations were measured according to the Lowry method.

\section{Enzyme properties of the chimeras}

Each moiety of both chimeras was assayed in parallel with the Xyn or Glu, respectively. Every data point was determined for three independent reactions, including protein concentration, substrate concentration, optimal reaction temperature $\left(\mathrm{T}_{\mathrm{opt}}\right)$, optimal reaction $\mathrm{pH}\left(\mathrm{pH}_{\mathrm{opt}}\right)$, residual activity, etc. The $\mathrm{pH}_{\mathrm{opt}}$ value was determined from $\mathrm{pH} 2.6-5.0$ in imidazole-biphthalate buffers. The Xyn moiety $\mathrm{T}_{\mathrm{opt}}$ was determined from $44-53{ }^{\circ} \mathrm{C}$, and residual activity was assayed after incubation at $50{ }^{\circ} \mathrm{C}$ at 10 -min intervals from $0-40 \mathrm{~min}$. The Glu moiety $\mathrm{T}_{\text {opt }}$ was determined from 78 to $96{ }^{\circ} \mathrm{C}$, and residual activity was assayed after incubation at $95{ }^{\circ} \mathrm{C}$ at 20 -min intervals from $0-60 \mathrm{~min}$. To indicate thermostability, residual activity was expressed as a ratio relative to the un-incubated enzyme activity, and the thermal inactivation half-life $\left(t_{1 / 2}\right)$ was calculated by fitting the data with the equation $y=A^{\prime \prime} e^{-k t}$ (Origin, version 8.0).

The kinetics were assayed at $\mathrm{T}_{\text {opt }}$ and $\mathrm{pH}_{\text {opt }}$ conditions using birch wood xylans at concentrations from $10-40 \mathrm{mg} / \mathrm{ml}$ for $5 \mathrm{~min}$ (Sigma-Aldrich, Shanghai, China). The kinetics for glucanase were assayed at $85{ }^{\circ} \mathrm{C}$ and $\mathrm{pH}_{\text {opt }}$ conditions using $\mathrm{CMC}$ at concentrations from $2.5-15 \mathrm{mg} / \mathrm{ml}$ for $5 \mathrm{~min}$. The data were fitted with the Hill function to calculate maximal activity $\left(\mathrm{V}_{\max }\right)$ and $\mathrm{K}_{\mathrm{m}}$ (Origin, version 8.0). Xylanase activity was determined toward birch-wood xylan and glucanase activity was determined toward CMC using the dinitrosalicylic acid (DNS) method described previously [4]. One unit of activity (U) was defined as the amount of enzyme that produced $1 \mu \mathrm{mol}$ xylose or glucose per minute.

\section{Competing interests}

The authors declare that they have no competing interests.

\section{Acknowledgements}

This work was supported by Natural Science Foundation of China (30972123) (20971050). The authors are grateful to lan Riley for his advice on paper writing and the anonymous reviewers for their sincere suggestions of the paper.

\section{Author details}

${ }^{1}$ Life Science College, Henan Agricultural University, 95 Wenhua Road, Zhengzhou, Henan 450002, China. ${ }^{2}$ School of Life Science, Huaiyin Institute of Technology, 3 Meicheng Road, Huaian, Jiangsu 223001, China. ${ }^{3}$ Key Laboratory of Enzyme Engineering of Agricultural Microbiology, 95 Wenhua Road, Zhengzhou, Henan 450002, China.

\section{Author's contributions}

Liu, L. conceived of the study and participated in its design. Wang, L., Zhang, Z., and Guo, X. carried out the molecular genetic studies. Li, X. and Chen, H. performed the statistical analysis. All authors read and approved the final manuscript.

Received: 2 January 2012 Accepted: 7 June 2012

Published: 7 June 2012

\section{References}

1. Bittker JA, Le BV, Liu JM, Liu DR: Directed evolution of protein enzymes using nonhomologous random recombination. Pro Natl. Acad. Sci. USA 2004, 101:7011-7016.

2. Sun JY, Liu MQ, Xu YL, Xu ZR, Pan L, Gao H: Improvement of the thermostability and catalytic activity of a mesophilic family 11 xylanase by N-terminus replacement. Protein Expr Purif 2005, 42:122-130.

3. Zhang S, Zhang K, Chen X, Chu X, Sun F, Dong Z: Five mutations in Nterminus confer thermostability on mesophilic xylanase. Biochem Biophys Res Commun 2010, 395:200-206.

4. Liu L, Cheng J, Chen H, Li X, Wang S, Song A, Wang M, Wang B, Shen J: Directed evolution of a mesophilic fungal xylanase by fusion of a thermophilic bacterial carbohydrate-binding module. Process Biochem 2011, 46:395-398.

5. Elleuche S, Piascheck H, Antranikian G: Fusion of the OsmC domain from esterase EstO confers thermostability to the cold-active xylanase Xyn8 from Pseudoalteromonas arctica. Extremophiles 2011, 15:311-317.

6. Lu P, Feng MG, Li WF, Hu CX: Construction and characterization of a bifunctional fusion enzyme of Bacillus-sourced $\beta$-glucanase and xylanase expressed in Escherichia coli. FEMS Microbiol Lett 2006, 261:224-230.

7. An JM, Kim YK, Lim WJ, Hong SY, An CL, Shin EC, Cho KM, Choi BR, Kang $J M$, Lee SM, Kim HYHD: Evaluation of a novel bifunctional xylanasecellulase constructed by gene fusion. Enzyme Microb Technol 2005, 36:989-995.

8. Hong SY, Lee JS, Cho KM, Math RK, Kim YH, Hong SJ, Cho YU, Kim H, Yun HD: Assembling a novel bifunctional cellulase-xylanase from Thermotoga maritima by end-to-end fusion. Biotechnol Lett 2006, 28:1857-1862.

9. Hong S, Lee J, Cho K, Math R, Kim Y, Hong S, Cho Y, Cho S, Kim H, Yun H: Construction of the bifunctional enzyme cellulase- $\beta$-glucosidase from the hyperthermophilic bacterium Thermotoga maritima. Biotechnol Lett 2007, 29:931-936.

10. Liebl W, Winterhalter C, Baumeister W, Armbrecht M, Valdez M: Xylanase attachment to the cell wall of the hyperthermophilic bacterium Thermotoga maritima. J Bacteriol 2008, 190:1350-1358.

11. Ahmed S, Riaz S, Jamil A: Molecular cloning of fungal xylanases: an overview. Appl Microbiol Biotechnol 2009, 84:19-35.

12. Chen $H$, Yan $X$, Liu $X$, Wang $M$, Huang $H$, Jia $X$, Wang J: Purification and characterization of a novel bifunctional xylanase, Xynlll, isolated from Aspergillus niger A-25. J Microb Biot 2006, 16:1132-1138.

13. Nam KH, Kim SJ, Hwang KY: Crystal structure of CelM2, a bifunctional glucanase-xylanase protein from a metagenome library. Biochem Biophys Res Commun 2009, 383:183-186.

14. Nelson KE, Clayton RA, Gill SR, Gwinn ML, Dodson RJ, Haft DH, Hickey EK, Peterson JD, Nelson WC, Ketchum KA, McDonald L, Utterback TR, Malek JA, Linher KD, Garrett MM, Stewart AM, Cotton MD, Pratt MS, Phillips CA, Richardson D, Heidelberg J, Sutton GG, Fleischmann RD, 
Eisen JA, White O, Salzberg SL, Smith HO, Venter JC, Fraser CM: Evidence for lateral gene transfer between Archaea and bacteria from genome sequence of Thermotoga maritima. Nature 1999, 399 (6734):323-329.

15. Li X, Shao W: The construction of Thermotoga maritima endoglucanase Cel $12 B$ fused with CBD and the characterization of chimeric enzyme. Acta Microbiol Sin 2006, 46:726-729.

16. Sunna A, Gibbs MD, Bergquist PL: The thermostabilizing domain, XynA, of Caldibacillus cellulovorans xylanase is a xylan binding domain. Biochem $J$ 2000, 346:583-586.

17. Lu P, Feng MG: Bifunctional enhancement of a beta-glucanase-xylanase fusion enzyme by optimization of peptide linkers. Appl Microbiol Biot 2008, 79:579-587.

18. Fan Z, Werkman JR, Yuan L: Engineering of a multifunctional hemicellulase. Biotechnol Lett 2009, 31:751-757.

19. Mitra T, Sailakshmi G, Gnanamani A, Thirupathi Kumara Raja S, Thiruselvi T, Mangala Gowri V, Selvaraj N, Ramesh G, Mandala AB: Preparation and characterization of a thermostable and biodegradable biopolymers using natural cross-linker. Int J Biol Macromol 2011, 48:276-285.

20. Liu L, Zhang G, Zhang Z, Wang S, Chen H: Terminal amino-acids disturb Xylanase thermostability and activity. J Biol Chem 2011, 286:44710-44715.

doi:10.1186/1472-6750-12-28

Cite this article as: Liu et al:: Domain-swapping of mesophilic xylanase with hyper-thermophilic glucanase. BMC Biotechnology 2012 12:28.

\section{Submit your next manuscript to BioMed Central and take full advantage of:}

- Convenient online submission

- Thorough peer review

- No space constraints or color figure charges

- Immediate publication on acceptance

- Inclusion in PubMed, CAS, Scopus and Google Scholar

- Research which is freely available for redistribution 